\title{
Технонаціоналістичні тенденції розвитку глобальних акторів військових інновацій
}

\author{
Надія Скляр ${ }^{1 \mathrm{~A}}$ \\ А Донецький юридичний інституту МВС України, м. Кривий Ріг, 50000, Україна
}

Received: March 03, 2021 | Revised: April 18, 2021 | Accepted: April 30, 2021

JEL Classification: 014, 032, O38, P52.

DOI: $10.33445 /$ sds.2021.11.2.7

\begin{abstract}
Анотація
Стаття присвячена дослідженню теорії та практиці однієї із шкіл управління національною конкурентоспроможністю - технонаціоналізму. Метою дослідження $€$ визначення особливостей розвитку сучасного технонаціоналізму, практик управління національної конкурентоспроможності в секторі оборонної промисловості країн світового технологічного ядра та окреслення потенційних загроз впливу впровадження такої політики на глобальну та національні безпеки інших країн.

Розглянуті специфічні характеристики сучасних технологій, які пов'язані з подвійним використанням. Досліджена рейтингова позиція країн-лідерів по технологіям за секторами економіки з визначенням особливостей технонаціоналістичних політик європейських та азійських країн. Зазначені фундаментально-ідеологічні відмінності між двома системами. Визначено сучасні інноваційні тренди технологій, які пов'язані з технологіями подвійного використання США та Китаю. Доведено посилення впливу уряду Америки на інші ринки новітніх технологій країн світу.

Розглянуто тяжіння технонаціональної політики Пекіну до нових квантових розробок (QC), що обумовлює не тільки підвищення воєнно-технологічного потенціалу країни, а й можливі майбутні виклики глобального та регіонального масштабів. Окреслені технологічні тенденції розвитку інноваційних технологій, що викликають стурбованість світової спільноти та можуть бути підставами формування національних та глобальних ризиків та загроз безпеці.
\end{abstract}

Ключові слова: технонаціоналізм, військові технологічні інновації, науково-технічні інвестиції, глобальні та національні виклики.

\section{Постановка проблеми}

Оцінка потенційного впливу науковотехнічного розвитку на економічну конкурентоспроможність кожної країни та її військовий потенціал залежить від науковотехнічного планування національної безпеки; ймовірного поступу науково-технічного розвитку протягом наступних 3-5 років та подальших 10 років; орієнтовного часу, необхідного для досягнення поставлених цілей; пріоритетів науково-технічних досліджень з високим потенційним впливом на економічну конкурентоспроможність та військовий потенціал; індивідуальні показники прогресу для досягнення національних цілей [1, с. 81]. Але сучасний нестабільний економічний та політичний розвиток, військова модернізація, науковотехнічні інвестиції, світові пандемічні обмеження в умовах глобальної небезпеки формують інші політико-економічні тенденції роботи урядів багатьох країн світу та мають різні вектори впливу на формування

\footnotetext{
${ }^{1}$ Corresponding author: к.е.н., докторант Національного інституту стратегічних досліджень, доцент кафедри державно-правових дисциплін, е-таіl: test20@ukr.net, ORCID: 0000-0001-9122-340X
} 
військово-економічної стратегії не тільки країн, які розвиваються, а й глобальних світових гравців.

Гонитва багатьох держав за впровадженням технологічних мегатрендів четвертої промислової революції в військове виробництво та виробництво товарів подвійного використання обумовлює специфіку розвитку політики техноглобалізму та технонаціоналізму в практиці управління національної конкурентоспроможності глобальних акторів військових інновацій, які по різному оцінюють можливість держави впливати на інноваційну технологічну діяльність в межах своїх кордонів. Дослідження особливостей розвитку сучасного технонаціоналізму провідних країн дозволяє визначити напрямки стратегічного розвитку підприємств оборонної галузі України та скорегувати національні пріоритети у військово-економічній безпеці держави.

\section{Аналіз останніх досліджень та публікацій}

Теорія національної конкурентоспроможності висвітлена в працях М. Портера [2], Дж. Сакса [3]. Українськими дослідниками економічної безпеки розглядалися питання конкурентних стратегій безпеки розвитку України та її сектору безпеки у глобальному середовищі (Д. Антонюк, І. Бабець, А. Мокій [4]), удосконалення інституційної інфраструктури інноваційного розвитку та вплив на формування військового потенціалу країни (О. Власюк [5], В. Бегма [6], В. Горбулін [7]. А. Сухоруков [8]). Питання впливу науковотехнічного розвитку на військово-економічні бюджети різних країн світу розглядалися в доробках закордонних науковців та фахівців J. Yildirim, N. Öcal [9], U. Heo, M. Ye. [10], R. K. Biswas, E. Kabir, R. Rafi [11], P. Dunne, R. P.
Smith [12]. Питання технонаціоналізму розглядалися в працях Г. Андрощук [13], Д. Єфремова [14], Ж. Мінгальової [15].

Але сучасна політика технонаціоналізму та ії вплив на розвиток військових технологій та технологій подвійного використання країн світу, у національних та закордонних доробках розглядалася дотично. Впровадження технологічних мегатрендів четвертої промислової революції в військове виробництво тягне за собою не тільки позитивні аспекти зміцнення обороноздатності країни, а й виклики та ризики національним системам безпеки як глобальних акторів військових інновацій, так i менш інноваційно-розвиненим країнам, що і обумовлює напрямок та актуальність цього дослідження.

\section{Постановка завдання}

Метою статі $\epsilon$ дослідження особливостей розвитку сучасного технонаціоналізму, практик управління національної конкурентоспроможності В секторі оборонної промисловості країн світового технологічного ядра та визначення потенційних загроз впливу впровадження такої політики на глобальну та національні безпеки інших країн.

\section{Виклад основного матеріалу}

Згідно з теорією національної конкурентоспроможності М. Портера у конкурентному зростанні країн виділяють чотири стадії: 1) факторів; 2) інвестицій; 3) інновацій; 4) багатства [2].

Українські дослідники міжнародного менеджменту інноваційної діяльності Бабець І.
Г., Полякова Ю. В., Мокій О. А. приходять до висновку, що необхідними умовами переходу на вищу стадію конкуренто-здатності $\epsilon$ : механізм формування факторів виробництва (кількість та якість факторів, їх постійний розвиток); мотивація менеджерів; внітрішньогалузева конкуренція; удоскона-лення попиту; 
нестача окремих факторів як стимул до їх заміщення на базі передових досягнень; здатність до організації нового бізнесу [3, с. 11].

До специфічних характеристик сучасних технологій відносять вузьку спеціалізацію, швидке старіння, необхідність постійного розвитку, високий фінансовий ризик, швидке розповсюдження, розробка і впровадження ноу-хау та ін. Ці характеристики обумовлюють невизначеність та нерівномірність науковотехнічного прогресу, складність збереження лідерських позицій. Використовуючи вже розроблені та відомі у світі передові технології, можна перейти лише до інвестиційної стадії розвитку. Своєю чергою стадія інноваційного розвитку передбачає існування в економіці певного технологічного монополізму, який можна отримати лише в результаті власних передових наукових розробок. Характерна особливість глобальної економіки XXI століття це збільшення розриву між країнами, які нагромадили науково-виробничий потенціал для глобальної конкуренції, й країнами, у яких він ще не створений. У провідних країнах світу до 60\% підприємств щорічно впроваджують продукцію на основі нових знань та технологічних рішень, а витрати на науку і проектні роботи перевищують 3\% обсягу ВВП. Країни світового технологічного ядра (США, Японія, Німеччина, Великобританія, Франція), прийшли до інноваційної моделі економіки еволюційним шляхом, лідируючи ще на індустріальному етапі розвитку, і в даний час розвиваються переважно на основі активізації інноваційної діяльності [3, с. 13].

За оцінками Дж. Сакса, світ розділився на три регіони - розвинена частина, яка виробляє інновації; частина, що розвивається і використовує розроблені технології та відстала, стогнуюча частина. Менша частина планети (близько 15\% населення) забезпечує практично всі інші країни світу технологічними інноваціями. Друга частина (близько половини населення) здатна впроваджувати ці технології у виробництво і споживання. I решта (близько третини населення) $€$ технологічно відірваною - не виробляє інновації і не впроваджує їх [16, c. 100].

Відомо, що розрив у технологіях подолати набагато складніше, ніж розрив у залученні капіталів. Інновації демонструють зростаючу віддачу залежно від масштабу - регіони, що володіють довершеними технологіями, отримають переваги для нових інновацій.

Як показує світовий досвід, регулювання інноваційних процесів, тобто конкретний набір методів і важелів, більшою мірою залежить від економічних реалій та традицій управління економічним розвитком, ніж від соціальноекономічних та інституційних підвалин суспільства. Зокрема, розвинені країни надають перевагу адміністративним обмеженням, пострадянські країни-ринковим механізмам [17, с. 3].

Сьогодні виокремлюють вже сформовані типи організації інноваційного процесу, що мають практичне застосування в різних країнах: ринково-орієнтований (США), банківськоорієнтований (Німеччина), програмноорієнтований (Франція), корпоративноорієнтований (Японія, Республіка Корея), директивно-керований (країни 3 командноадміністративної економікою) [17].

Інновації, перетворюючись на "промислову релігію”, становляться компаній способом збільшення прибутку та захоплення ширшого сегмента ринку, а для урядів - засобом прискорення економічного зростання та підвищення конкурентоспроможності.

В теорії та практиці управління національної конкурентоспроможності склалися дві школи, які по різному оцінюють можливість держави впливати на інноваційну технологічну діяльність в межах своїх кордонів. Технонаціоналізм - термін, який використовується для опису національної політики, яка націлена на всебічний захист національних фірм від міжнародної конкуренції і яка намагається безпосередньо впливати на технологічний розвиток в країні. Технонаціоналізм - це сукупність меркантилістських політик, які пов'язують технічні інновації та підприємництво безпосередньо 3 політикою національної 
безпеки, економічного процвітання та соціальної стабільності нації [18]. Це політика високих технологій, що має відношення до наукових досліджень, промислової конкурентоспроможності та стимулювання експорту.

Технонаціоналізм характерний для багатьох країн Європи, а також для США. Американськокитайська торгова війна лише один із прикладів нового системного суперництва двох наддержав світу. Ця конкуренція покриває весь геополітичний спектр і охоплює всі аспекти виробництва інших країн. Фундаментальноідеологічні відмінності між двома системами починають мати вплив далеко за кордонами Китаю та США. Де-факто, вони мають розвиватися через взаємопереплетену мережу глобальних ланцюгів створення вартості. Однак крізь десятиріччя глобалізації, де нормою стало офшорне виробництво, відбувається зміщення торгівельного ландшафту у напрямку більш фрагментованої та локалізованої моделі під назвою "технонаціоналізм".

Техноглобалізм розглядає інноваційну технологічну політику протекціонізму як марну в світі, де промисловість високих технологій стала транснаціональною. Ті з учених, хто поділяє цей погляд, вважають, що занадто багато приділяється уваги національній політиці в світі, де національні відмінності між фірмами стираються, а відмінності між націями полягають не стільки в національну приналежність капіталу або особливості управління, скільки в інституційних відмінностях та відмінностями між національними системами інновацій [15].

Ключова складова політики Швеції, Німеччини, Японії, Швейцарії, орієнтованих на поширення технологій та намагання забезпечення можливості технологічних змін у всіх структурах за рахунок широкого та вільного трансферу технологічних інновацій - це існування необхідних механізмів та сильних інституцій, котрі сприяли би обміну технологій між бізнесом та дослідницьким сектором.

Як зауважує Мінгальова Ж., основною проблемою при реалізації цієї політики стало формування ефективних зв'язків і довірчих відносин між дослідницькими інститутами та фірмами, які $€$ вирішальними для створення плідних технологічних відносин. Німеччина, Швейцарія і Швеція мають інституційні та промислові структури, які заохочують переміщення наукових технологічних розробок між дослідним і виробничим секторами, а також між військовим і цивільним виробництвом [15].

Японське ліцензування американських військових технологій та спільне виробництво допомогло національним фірмам досягти найвищої ефективності виробництва і конкурентоспроможності. При цьому, як показує досвід, для формування національної конкурентоспроможності більш важливим $€$ комбінація інституційних і культурних сил, які включають національну систему інновацій в кожній країні, ніж специфічні типи наукової та технологічної політики. Ця система визначає мету, так само як і засоби економічного прогресу. Система інновацій включає в себе інституційні структури, заведений політичний порядок, форми організації праці, політичну i торгівельну логіку [15].

Таким чином, соціально-економічних показники, політика в галузі розповсюдження технологічних інновацій, географічне положення країни, особливості національних культур обумовлюють вибір відповідної моделі стимулювання національної конкурентоспроможності.

Все більше й більше країн, впроваджуючи політику технонаціоналізму, пов'язують їі 3 політикою національної безпеки. Технонаціоналізм розглядає державне втручання на ринки, як форму захисту від усього, що в цій політиці вважається опортуністичним і надає шанс на успіх національному виробнику. Але в сферах новітніх технологій, де беззаперечним лідером $\epsilon$ США, під прапором технонаціоналізму в останні роки вбачається посилення впиву на інші ринки технологій з боку уряду Америки. Так, наприклад, він досліджує можливості спрямування грошей до європейських 
телекомунікаційних компаній Nokia та Ericsson в спробі протистояти домінуванню Huawei в наступному поколінні бездротових технологій. Цей вид технонаціоналістичного обгрунтування $€$ новим для Вашингтону та обумовлюється необхідністю знаходження конкурента для Huawei. Фінансування Nokia та Ericsson $\epsilon$ спробою Вашингтону протидіяти багатомільярдній кредитній лінії і іншій фінансові допомозі, котру Huawei отримує від уряду Китаю через державну власність підприємств та банків. Урядова допомога дозволила Huawei пропонувати дешевші ціни за високу якість обладнання під час торгів за контрактами по всьому світу та накопити “військову фінансову скриню" компанії Huawei для досліджень та розробок високотехнологічних товарів подвійного використання. Також на міжнародному фронті США планують протидіяти поясу Китаю за допомогою дорожньої ініціативи, схваливши розширення приватної закордонної Інвестиційної корпорації (ОРІC) в нове агентство та Корпорації розвитку (IDFC) зі спільним інвестуванням близько 60 млрд дол США в компанії як американського так i неамериканського приватного сектору [19].

Отже, США займають провідні позиції серед країн-лідерів по технологіям, майже по усім секторам економіки, але 3 найбільшим показником у $80.4 \%$ серед усіх секторів військовий, космічний, оборонний (таблиця 1).

Таблиця 1 - Рейтинг країн - лідерів по технологіям за секторами економіки, 2019р.

\begin{tabular}{|c|c|c|c|c|c|c|c|c|}
\hline Країни Сектори & США & Китай & Франція & Німеччина & Японія & PФ & Корея & \begin{tabular}{|l} 
Велика \\
Британія
\end{tabular} \\
\hline Передові матеріали & $56.0 \%$ & $35.2 \%$ & $2.2 \%$ & $16.0 \%$ & $14.8 \%$ & $5.6 \%$ & $6.0 \%$ & $4.2 \%$ \\
\hline $\begin{array}{l}\text { Сільське господарство / } \\
\text { Харчування }\end{array}$ & $60.6 \%$ & $24.2 \%$ & $6.3 \%$ & $8.5 \%$ & $5.8 \%$ & $5.6 \%$ & $2.2 \%$ & $4.0 \%$ \\
\hline Автомобільна & $31.3 \%$ & $16.0 \%$ & $4.2 \%$ & $36.0 \%$ & $39.8 \%$ & $1.5 \%$ & $12.6 \%$ & $2.9 \%$ \\
\hline $\begin{array}{l}\text { Комерційна } \\
\text { аерокосмічний }\end{array}$ & $69.9 \%$ & $14.7 \%$ & $15.3 \%$ & $10.3 \%$ & $5.2 \%$ & $13.4 \%$ & $2.9 \%$ & $6.8 \%$ \\
\hline $\begin{array}{l}\text { Обчислювальна техніка / } \\
\text { ІТ }\end{array}$ & $59.0 \%$ & $38.9 \%$ & $3.3 \%$ & $6.1 \%$ & $14.4 \%$ & $9.2 \%$ & $8.3 \%$ & $5.9 \%$ \\
\hline Енергія & $52.7 \%$ & $25.2 \%$ & $10.9 \%$ & $22.9 \%$ & $11.2 \%$ & $12.0 \%$ & $5.5 \%$ & $6.4 \%$ \\
\hline Екологія / стійкість & $34.1 \%$ & $12.0 \%$ & $19.4 \%$ & $34.5 \%$ & $18.2 \%$ & $4.6 \%$ & $4.6 \%$ & $14.7 \%$ \\
\hline $\begin{array}{l}\text { Інформація / комунікації } \\
\text { / технології }\end{array}$ & $59.3 \%$ & $38.5 \%$ & $5.2 \%$ & $10.0 \%$ & $16.6 \%$ & $8.8 \%$ & $9.9 \%$ & $7.4 \%$ \\
\hline Електроніка & $47.3 \%$ & $36.6 \%$ & $4.7 \%$ & $19.1 \%$ & $25.5 \%$ & $5.8 \%$ & $13.6 \%$ & $6.8 \%$ \\
\hline $\begin{array}{l}\text { Наука про життя / } \\
\text { охорона здоров'я }\end{array}$ & $63.7 \%$ & $11.7 \%$ & $13.4 \%$ & $21.7 \%$ & $13.6 \%$ & $5.3 \%$ & $5.2 \%$ & $16.5 \%$ \\
\hline $\begin{array}{l}\text { Військова / космічна / } \\
\text { оборонна }\end{array}$ & $80.4 \%$ & $23.1 \%$ & $5.8 \%$ & $8.4 \%$ & $6.0 \%$ & $24.4 \%$ & $7.6 \%$ & $6.1 \%$ \\
\hline & & \multicolumn{3}{|c|}{$\begin{array}{c}\text { Країна-лідер у галузі } \\
\text { технологій }\end{array}$} & & \multicolumn{3}{|c|}{$\begin{array}{l}\text { Країна, що займає друге } \\
\text { місце в галузі технологій }\end{array}$} \\
\hline
\end{tabular}

Джерело: R\&D World, 2020 Global R\&D Funding Forecast, P.31 [20]

За останнє десятиріччя такі країни, як Китай та Сінгапур демонструють значний прогрес в напрямку розвитку науково-технічних стратегій, рушіями змін яких $\in$ інновації в галузі науки і техніки, програми котрих очолювані як урядами цих країн так і приватними особами та організаціями. Характерними особливостями цих країн $€$ швидке зростання ВВП та населення з 2010 р. до 2018 р., ресурсне обмеження, але суттве зростання науково-технічних інвестицій, які генерують економічне зростання та військову модернізацію. 


\begin{tabular}{lrrl}
\hline \multicolumn{1}{c}{ Державний } & менеджмент & представлений & прихильності до інновацій [1, с. 83]. Останнім \\
ефективним & управлінням & динамічного & часом увага Пекіна прикута до нових квантових \\
напруження між їх сильною & інвестиційною & розробок (QC). Станом на березень 2019 р. \\
стратегією зверху вниз та розвитком наукового & Китай вклав 10000 млн дол США державного \\
середовища знизу вгору. Ïх самодержавні & фінансування у сферу досліджень квантових \\
політичні системи демонструють надзвичайну & обчислень (QC) (Мал. 1).
\end{tabular}
важливість лідерства у розвитку стійкої

China-National Laboratory for Quantum
Information Sciences (2017-2020)
United States_-National Quantum
Initiative Act (NQIA) (2019-2023)
European Union-Quantum Technologies
Flagship Program (2016-2026)
Germany-Quantum technologies
framework program (2018-2022)
United Kingdom-Total quantum technology \&
computing funding (2019-2024)
Japan-Quantum computing government
fund (2018-2028)
The Netherlands-QuTech quantum
technology institute (2018-2028)
Sweden-Foundation research program
(2017-2027)
Australia-University funding program
South Korea-Quantum computing technology
development project (2019-2023)
Singapore-Quantum Engineering Programme

Total funding in million US dollars

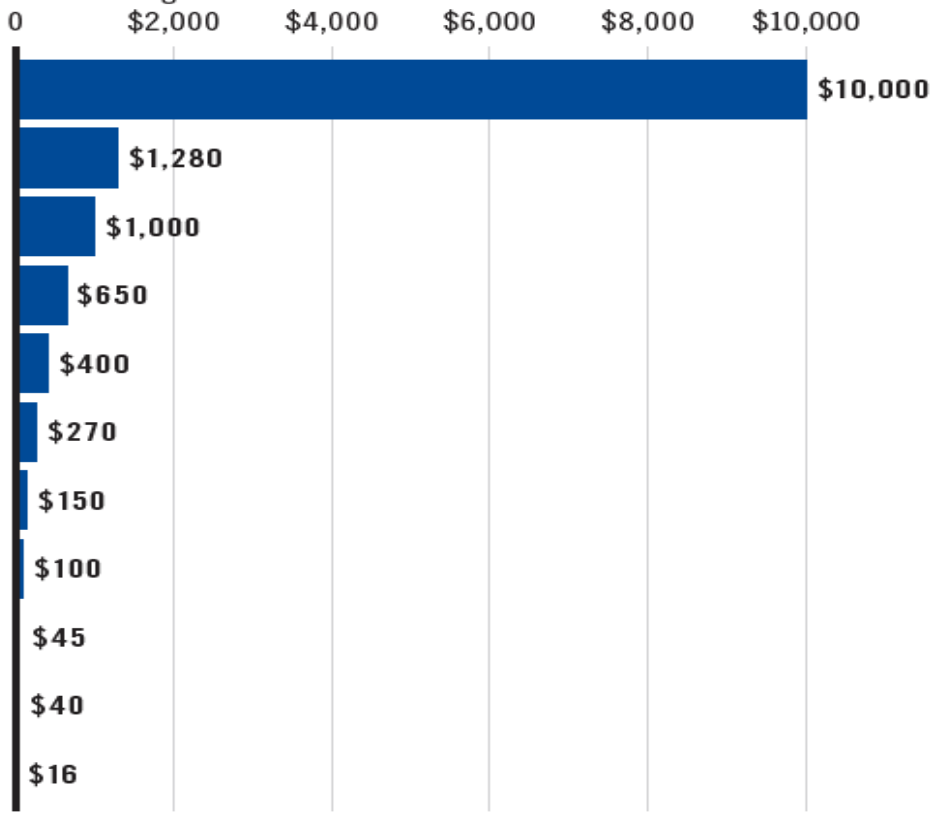

Малюнок 1 - Державні інвестиції країн світу в квантові дослідження, 2019 р.

Джерело: [21]

Західні спецслужби дуже занепокоєні стрімким китайським прагнення досягти провідної позиції у галузі квантових технологій. Зважаючи на цивільновійськового партнерство Китаю з Росією, розвиток інновацій, досліджень та суттєвого фінансування китайських збройних сил, У випадку військового протистояння, прогнози експертів схиляються до того, що наступна війна буде виграна за допомогою технологічного прогресу, не нехтуючи навіть “експериментальними" полями [21]. Якщо китайські фахівці будуть дотримуватися чітких стандартів європейської якості, то вважається, що країна стане лідером 3 великою перевагою в секторі розвідувальних операцій та шифрування та результуючі вдосконалені системи озброєння - збільшить геополітичні та бойові варіанти, що загрожують Заходу.

Такі виклики гарантують підвищену увагу урядів країн-лідерів воєнних інновацій та змушують до перегляду їх інноваційноінвестиційну політику в наступні роки.

Але активний розвиток технологій обумовлює зростання нових загроз, в тому числі і в військово-економічному секторі країн світу. Бурхливе зростання технологій, особливо інформаційних технологій, розширює можливості нинішніх і потенційних супротивників, особливо якщо їх мета - не копіювати можливості глобальних оборонних гравців світу, а протидіяти їм. Серед технологічних тенденцій, що викликають стурбованість, можна виділити наступні:

наявність знань і технологій, необхідних для виробництва і застосування зброї масового знищення, в тому числі і бактеріологічної;

балістичні ракети великої дальності, які стають все більш мобільними, точними і їх важче знайти. Балістичні ракети все частіше розробляються або використовуються для 
прориву передових систем протиракетної оборони країн;

саморобні пристрої та зброя з широким обсягом ураження для самогубців;

зростаюча здатність націлювати і атакувати об'єкти космічного зв'язку, спостереження та розвідки;

поширення високоточних звичайних протитанкових, протикорабельних і зенітних ракет, в тому числі серед недержавних злочинних або терористичних мереж;

витончена здатність обраних націй і недержавних груп використовувати і можливість атакувати комп'ютерні мережі державних та військових об'єктів країн;

розміщення техніки і технологій злочинними військовими угруповуваннями та терористичними організаціями 3 ціллю приховати і захистити своє військове керівництво і програми спеціальних озброєнь глибоко під землею, що робить їх все більш важкими для виявлення і ліквідації [1]; доступність штучного інтелекту та квантових розробок приватним збройним формуванням, особливо в нестабільних країнах та країнам з агресивною зовнішньою політикою;

масовий роботизованих комплексів різного призначення, розвідувальних БПЛА, важких ударних безпілотних літальних апаратів та відставання в організації національного та міжнародного контролів та правового забезпечення трансферу таких технологій навіть в провідних країнах - розробниках [22].

Таким чином, швидкі темпи технологічних змін, включаючи розробки в галузі штучного інтелекту і синтетичної біології, квантових розробок, нових форм БПЛ та роботизованих систем, посилюють загрози міжнародної безпеки і все більше ускладнюють політичний та правовий нагляд за новими технологіями.

\section{Список використаних джерел}

1. National Research Council; Division on Engineering and Physical Sciences; Standing Committee on Technology Insight-Gauge. (2010, August 12). S\&T strategies of six countries: Implications for the United States. https://doi.org/10.17226/12920.

2. Competitive Strategy. Book by Michael E. Porter | Official Publisher Page / Simon \& Schuster. Free Press. Web. 02 Mar. 2021.

3. Бабець І.Г., Полякова Ю.В., Мокій О.А. Міжнародний менеджмент інноваційної діяльності: підручник за заг. ред. І. Г. Бабець, А. І. Мокія. Запоріжжя: Кругозір, 2016. 496c.

4. Конкурентні стратегії безпеки розвитку України у глобальному середовищі: монографія. За заг. ред. А. І. Мокія. Львів: ДУ «Інститут регіональних досліджень імені М. І. Долішнього НАН України», 2019. 872c.

5. Структурно-інституціональні трансформації та економічна безпека держави: монографія. За заг. ред. О.В. Власюка, А. І. Мокія. Львів: Апріорі, 2012.С. 836.

6. Бегма В.М., Скляр Н.М. Ризики експортного контролю та воєнно-економічна безпека держави. Стратегічні пріоритети. № 2, 2014. С. 98-104.

7. Горбулін В.П. Оборонне будівництво в Україні: проблемні питання розвитку ОПК і підходи до їх вирішення. Стратегічна панорама. № 1-2. 2001. С. 135-142.

8. Система економічної безпеки держави: монографія. За заг. ред. А.І. Сухорукова. Національний інститут проблем міжнародної безпеки при РНБО України. Київ: ВД «Стилос», 2009. С. 685.

9. Yildirim, J. \& Öcal, N. (2016). Military expenditures, economic growth and spatial spillovers. Defence and Peace Economics, 27(1), 87-104. https://doi.org/10.1080 / 10242694.2014.960246

10. Heo, U. \& Ye, M. (2016). Defense Spending and Economic Growth around the Globe: The Direct and Indirect Link. International Interactions, 42(5), 774-796. DOI: 10.1080/03050629.2016.1149067

11. Biswas, R. K., Kabir, E. \& Rafi, RBR. (2019). Investment in Research and Development Compared to Military Expenditure: Is 
Research Worthwhile? Defence and Peace Economics, 30(7), 846-857. DOI: 10.1080/10242694.2018. 1477235

12. Dunne, J.P. \& Smith, R.P. (2020). Military Expenditure, Investment and Growth. Defence and Peace Economics,31(6), 601614. DOI: $10.1080 / 10242694.2019 .1636182$

13. Андрощук Г.О. Національна інноваційна система Фінляндії: формула успіху. Наука та інновації. 2010. Т. 6, № 4. С. 93-107.

14. Єфремов Д. П. Стратегічний підхід до розвитку науки та інновацій: китайський приклад. Scientific Journal "ScienceRise» No9/1(14). 2015. C. 36-41. DOI: 10.15587/2313-8416.2015. 50313

15. Мингалева Ж. А. Инновационная активность и формирование национальной конкурентоспособности. Вектор науки тГУ. Серия: Экономика и управление. 2013. № 1(12). С. 96-99.

16. Лазутін Г. І. Сучасні тенденції розвитку інноваційної діяльності. Економіка $і$ прогнозування. 2005. №2. С. 99-113.

17. Захарін С. В., Коваленко Д. Міжнародний досвід управління інноваційним розвитком регіонів та можливості його використання в Україні. Проблеми науки. 2011. №11. C.2-8.

18. Malecki, Ed. J. (2020). Technology \& Economic Development: The Dynamics of Local, Regional and National
Competitiveness. Second Edition. Addison Wesley Longman Ltd., Essex.

19. Capri, A., Mark A. Cohen, M.A., Dupont, A., Olson, St., \& Paterson, St. (2021). "US-China Tech Innovation Race." Hinrich Foundation. Web. 03 Mar. 2021. Available from: https://www.hinrichfoundation.com/researc h/wp/tech/us-china-tech-innovation-race/

20. R\&D World (2020) Global R\&D Funding. Forecast, 31 . Available from: https://forecast.rdworldonline.com/product /2021-global-rd-funding-forecast

21. Catechis, K. (2020). 2021 and beyond: Technology remains a key geopoliticial battleground. 2021 Outlook: Vulnerability and resiliency through upheaval. Franklin Templeton Thinks, 23. Available from: https://www.franklintempleton.com.cn/con tent-ftthinks/common/gio/2021-globalinvestment-outlook/2021-outlookvulnerability-and-resiliency-throughupheaval-a.pdf

22. Скляр Н. Мегатренди розвитку технологій подвійного використання в глобальному безпековому вимірі. Міжнародна ma начіональна безпека: теоретичні $i$ прикладні аспекти: зб.матеріалів V міжнародній науково-практичній конференції. Дніпро: ДДУВС, 2021. С. 231235.

\section{Технонационалистические тенденции развития глобальных актеров военных инноваций}

\footnotetext{
Надежда Скляр * А

* Corresponding author: к.е.н., докторант Национального института стратегических исследований, e-mail: test20@ukr.net, ORCID: 0000-0001-9122$340 \mathrm{X}$

А Донецкий юридический институт МВД Украины, ул. Степана Тельги, 21, 50000, г. Кривой Рог, Украина Аннотация

Статья посвящена исследованию теории и практики одной из школ управления национальной конкурентоспособности - технонационализму. Целью исследования является выявление особенностей развития современного технонационализма, практик управления национальной конкурентоспособности в секторе оборонной промышленности стран мирового технологического ядра и определение потенциальных угроз влияния внедрения такой политики на глобальную и национальные безопасности других стран.
} 
Рассмотрены специфические характеристики современных технологий, связанных с двойным использованием. Исследована рейтинговая позиция стран-лидеров по технологиям по секторам экономики с определением особенностей технонационалистичних политик европейских и азиатских стран. Указаны фундаментально-идеологические различия между двумя системами. Определены современные инновационные тренды технологий, связанных с технологиями двойного использования США и Китая. Доказано усиления влияния правительства Америки на другие рынки новейших технологий стран мира.

Рассмотрены ориентиры технонациональной политики Пекина к новым квантовым разработкам (QC), что обусловливает не только повышение военно-технологического потенциала страны, но и возможные будущие вызовы глобального и регионального масштабов. Определены технологические тенденции развития инновационных технологий, которые вызывают обеспокоенность мирового сообщества и могут быть основаниями формирования национальных и глобальных рисков и угроз безопасности.

Ключевые слова: технонационализм, военные технологические инновации, научнотехнические инвестиции, глобальные и национальные вызовы.

\title{
Technonationalist trends in the development of global actors of military innovation
}

\author{
Nadiia Skliar * A \\ * Corresponding author: PhD in Economics, Post-Doctoral Fellow, National Institute for Strategic Studies, e-mail: test20@ukr.net, ORCID: 0000-0001-9122- \\ $340 \mathrm{X}$ \\ A Donetsk Law Institute MIA of Ukraine, 21, S. Tilgyi str., Kryvyi Rih, 50000, Ukraine
}

\begin{abstract}
The article is devoted to the study of the theory and practice of one of the schools of management of national competitiveness - techno-nationalism. The aim of the study is to identify the features of the development of modern techno-nationalism, the practices of managing national competitiveness in the defense industry sector of the countries of the world technological core, and to identify potential threats to the impact of the implementation of such a policy on the global and national security of other countries.

The specific characteristics of modern technologies associated with dual-use are considered. The rating position of the leading countries in terms of technologies by sectors of the economy has been investigated, with the definition of the features of techno-nationalist policies of European and Asian countries. The fundamental ideological differences between the two systems are indicated. The current innovative technology trends associated with dual-use technologies in the United States and China have been identified. The increasing influence of the American government on other markets for the latest technologies in the countries of the world has been proven.

The guidelines of Beijing's techno-national policy towards new quantum computing (QC) are considered, which determines not only an increase in the country's military-technological potential but also possible future challenges on a global and regional scale. The technological trends in the development of innovative technologies that cause concern of the world community and can be the basis for the formation of national and global risks and threats to security have been identified.
\end{abstract}

Keywords: techno-nationalism, military technological innovations, scientific and technological investments, global and national challenges. 


\section{References}

1. National Research Council; Division on Engineering and Physical Sciences; Standing Committee on Technology Insight-Gauge. (2010, August 12). S\&T strategies of six countries: Implications for the United States. DOI: 10.17226/12920.

2. "Competitive Strategy." Book by Michael E. Porter / Official Publisher Page / Simon \& Schuster. Free Press. Web. 02 Mar. 2021.

3. Babets, I., Polyakova, Y., Mokiy A. (2016). Mizhnarodny `j menedzhment innovacijnoyi diyal'nosti: pidruchny'k [International Management Innovation: a textbook]. Zaporizhye: Horizon, 496 p.

4. Konkurentni strategiyi bezpeky' rozvy'tku Ukrayiny' u global'nomu seredovy'shhi: monografiya. Za zag. red. A. I. Mokiya. ["Competitive security strategies of Ukraine's development in the global environment: monograph". For the general ed. A.I. Mokiy](2019). Lviv: DI "Insty'tut regional'ny'x doslidzhen' imeni M. I. Dolishn'ogo NAN Ukrayiny" [SI Dolishny Institute for Regional Studies of the National Academy of Sciences of Ukraine], 872p.

5. Strukturno-insty tucional'ni transformaciyi ta ekonomichna bezpeka derzhavy: monografiya. Za zag. red. O.V. Vlasyuka, A. I. Mokiya ["Structural and institutional transformations and economic security of the state": monograph. For the general ed. O.B. Vlasyuk, A.I. Mokiy]. (2012). L'viv: Apriori [Apriori], 836p.

6. Begma, V., Skliar, N. (2014). Ryzyky eksportnoho kontroliu ta voiennoekonomichna bezpeka derzhavy [Export Control Risks and Military and Economic Security of the State]. Stratehichni priorytety [Strategic Priorities], no. 2, 98-104.

7. Gorbulin, V. (2001). Oboronne budivny`cztvo $\checkmark$ Ukrayini: problemni py`tannya rozvy'tku OPK i pidxody' do yix vy 'rishennya [Defense construction in Ukraine: problematic issues of defense industry development and approaches to their solution]. Strategichna panorama [Strategic panorama], № 1-2,
135-142.

8. Sy`stema ekonomichnoyi bezpeky` derzhavy: monografiya. Za zag. red. A.I. Suxorukova. [The system of economic security of the state: a monograph. For the general ed. A.Suhorukov](2009). Nacional'ny'j insty'tut problem mizhnarodnoyi bezpeky ' pry` RNBO Ukrayiny”. Ky'yiv: VD "Stylos " [National Institute of International Security at the National Security and Defense Council of Ukraine. Kyiv: VD Stylos], 685p.

9. Yildirim, J. \& Öcal, N. (2016). Military expenditures, economic growth and spatial spillovers. Defence and Peace Economics, 27(1), 87-104. DOI: 10.1080/10242694.2014.960246

10. Heo, U. \& Ye, M. (2016). Defense Spending and Economic Growth around the Globe: The Direct and Indirect Link. International Interactions, 42(5), 774-796. DOI: 10.1080/03050629.2016.1149067

11. Biswas, RK., Kabir, E. \& Rafi, RBR. (2019). Investment in Research and Development Compared to Military Expenditure: Is Research Worthwhile? Defence and Peace Economics, 30(7), 846-857. DOI: 10.1080/10242694.2018. 1477235

12. Dunne, J. P. \& Smith, R. P. (2020). Military Expenditure, Investment and Growth. Defence and Peace Economics,31(6), 601614. DOI: $10.1080 / 10242694.2019 .1636182$

13. Androschuk, G. (2010). Nacional'na innovacijna sy`stema Finlyandiyi: formula uspixu [Finland's national innovation system: a formula for success]. Nauka ta innovaciyi [Science and innovation]. vol. 6, № 4. 93-107. 14. Efremov, D. (2015). Strategichny j pidxid do rozvy`tku nauky` ta innovacij: ky`tajs`ky`j pry`klad [Strategic approach to the development of science and innovation: a Chinese example]. Scientific Journal "ScienceRise», 9/1 (14),36-41. DOI: 10.15587/2313-8416.2015. 50313

15. Mingaleva, Zh. (2013). Innovatsionnaya aktivnost i formirovanie natsionalnoi konkurentosposobnosti [Innovative activity 
and the formation of national competitiveness]. Vektor nauki TGU. Seriya: Ekonomika i upravlenie [TSU science vector. Series: Economics and Management], 1(12), 96-99.

16. Lazutin, G. (2005). Suchasni tendenciyi rozvy'tku innovacijnoyi diyal'nosti [Recent trends in the development of innovative performance]. Ekonomika i prognozuvannya [Economy and forecasting], No. 2, 99-113.

17. Zakharin, S. \& Kovalenko, D. (2011). Mizhnarodny jo dosvid upravlinnya innovacijny'm rozvy'tkom regioniv ta mozhly`vosti jogo vy`kory`stannya v Ukrayini [International information on the management of the innovative development of regions and opportunities for the anniversary in Ukraine]. Problemy 'nauky' [Science problems]. 2011, №11, 2-8.

18. Malecki, Ed.J.(2020). Technology \& Economic Development: The Dynamics of Local, Regional and National Competitiveness. Second Edition. Addison Wesley Longman Ltd., Essex.

19. Capri, A., Mark A. Cohen, M.A., Dupont, A., Olson, St., \& Paterson, St. (2021). "US-China Tech Innovation Race." Hinrich Foundation. Web. 03 Mar. 2021. Available from: https://www.hinrichfoundation.com/researc h/wp/tech/us-china-tech-innovation-race/

20. R\&D World (2020) Global R\&D Funding. Forecast, 31. URL: https://forecast. rdworldonline.com/ product/2021-global-rdfunding-forecast

21. Catechis, K. (2020). 2021 and beyond: Technology remains a key geopoliticial battleground. 2021 Outlook: Vulnerability and resiliency through upheaval. Franklin Templeton Thinks, 23. Available from: https://www.franklintempleton.com.cn/con tent-ftthinks/common/gio/2021-globalinvestment-outlook/2021-outlookvulnerability-and-resiliency-throughupheaval-a.pdf

22. Skliar, N. (2021). Megatrendy' rozvy'tku texnologij podvijnogo vy`kory`stannya v global'nomu bezpekovomu vy'miri [Megatrends of development of dual-use technologies in the global security dimension]. Mizhnarodna ta nacional'na bezpeka: teorety 'chni i pry`kladni aspekty`: zb.materialiv $V$ mizhnarodnij naukovoprakty 'chnij konferenciyi [International and national security: theoretical and applied aspects: a collection of materials of the $V$ international scientific-practical conference]. Dnipro: DDUVS, 2021, 231-235. 